\title{
THE IOWA STATE FAIR: ITS FIRST SIX YEARS
}

\author{
by Dorothy Carlson, Editor
}

The Iowa State Fair, that collage of cotton candy, champion livestock, Midway hawkers, prize crops and the latest in machinery, has been held annually in Des Moines since 1879. Boasting a crowd of over a half million and premiums of near $\$ 200,000$, the modern attraction had its beginning 115 years ago in southern Iowa. Its parent was the Iowa State Agricultural Society, a group of men organized for the development of all facets of agriculture.

\section{lowa State Agricultural Society}

The Iowa State Agricultural Society first met in Fairfield Dec. 28, 1853, the seventh anniversary of statehood. Composed of representatives from five county agricultural societies, the group adopted a constitution and bylaws and elected its first officers: president, Thomas W. Claggett of Lee County; vice-president, D. P. Inskeep of Wappelo; recording secretary, Joshua M. Shaffer of Jefferson; corresponding secretary, C. W. Slagle of Jefferson; and treasurer, W. B. Chamberlain of Des Moines County. The purpose of the society, as stated in its constitution, was "the promotion of Agriculture, Horticulture, Manufactures, Mechanics and Household Arts." To this end, annual exhibitions were planned; members were encouraged to bring to the fair "the Stock, the Productions, the Fruits, the Mechanical Skill, the artistic excellence, the household economy, of all parts of the State [for] comparison; that the advantages and disadvantages, the superiorities, and deficiencies of one part may be compared with those of another part." Premiums, composed of diplomas from the society and monetary rewards, were offered for the best method or production.

\section{Fairfield (1854-55)}

The state society chose Fairfield as the location and Oct. 25, 26 and 27, 1854 as the dates for the first fair. Six acres of ground were procured and enclosed in a 10-foot high fence. According to the Fairfield Ledger of Nov. 2, 1854 
the first day was devoted to the exhibition of stock, and the second day to the display of agricultural implements, farm and dairy products, ladies' handiwork and various collections, such as those of reptiles, birds and daguerrotypes. The highlight of the second day, however, was female equestrianism. The first prize, a gold watch valued at $\$ 100$, was awarded to Miss Carrie Turner of Keokuk. The crowd disagreed strongly with the judges, favoring Eliza Jane Hodges of Iowa City. So angry were the spectators that a collection was taken up for Eliza (yielding \$165) and it was arranged for her to attend the Female Seminaries, tuition free, at Fairfield and Mount Pleasant. (Ladies' Horsemanship was to cause heated comment at later fairs.) The third day was quiet; the members of the society met, appointed officers for the coming year - Claggett continued as president and Shaffer as secretary - and decided upon Fairfield as the site of the 1855 exhibition. Attendance had totaled 8,500 and premiums, $\$ 1,171$.

Shaffer filled his position conscientiously. His report on the second annual fair is detailed and yields the following information. The Jefferson County Agricultural Society was given the responsibility of selecting the grounds and providing the accommodations for the fair, as it had the year before. For the 1855 fair 10 acres were purchased, of which seven were enclosed by a 6 -foot high fence. The area outside the fence was maintained for carriage ways and hitching posts. Inside the enclosure were built four display booths; offices for the secretary, treasurer and other officials of the fair; a bandstand and seating accommodations for over 2,000 people. The cost of $\$ 1,500$ was paid by the Jefferson society.

Thirty-two classes were established for the awarding of premiums; cash prizes ranged from $\$ 1$ to $\$ 10$ :

Classes 1 \& 2 Durham and Devon cattle, all ages (bulls, cows and calves)

Class 3 Sweepstake (bulls and cows)

Classes 4 \& 5 Native and grade stock (bulls, cows and calves)

Class 6 Work oven and beef (fat cattle)

Class 7 Milch [milk] cows

Class 8 Stallions, heavy and light draft, all ages 
Class 9 Brood mares, heavy and light draft, all ages

Class 10 Matches, buggy and saddle horses

Class 11 Jacks, jennets and mules

Class 12 Thoroughbred horses (stallions, mares, colts)

Class 13 Sweepstake (stallion)

Class 14 Sheep (long wool, fine wool)

Class 15 Swine (boars, sows, pigs, fat hogs)

Class 16 Poultry (Shanghais, Dorkings, Polands, Chittigongs, Brahma Pootras)

Class 17 Farm implements (wagons, cultivators, corn planters, fanning mills, ox yokes, prairie plows, sod plows, fallow plows, corn plows)

Class 18 Churn, horse shoes

Class 19 Farm machinery (reaper and mower, self raker, thresher and separator, threshing machine, pork barrel, "best Horse power")

Class 20 "Other articles of Mechanical Skill" (cooking stove, lot of tin ware, sculptural marble, bureau, set of chairs)

Class 21 Leather and its manufactures (kip skins, upper leather, sole leather, harnass leather, fine boots, coarse boots, saddle, buggy harness )

Class 22 Dairy products (butter, cheese, honey)

Class 23 Grain and seeds (white wheat, red wheat, oats, Timothy seed, flax seed, buckwheat, Irish potatoes, sweet potatoes, beets, parsnips, carrots, turnips, "newly introduced grain")

Class 24 Vegetables (cabbage, largest assortment, tomatoes, lima beans, squashes, sweet pumpkins)

Class 25 Cloth (table linen, tow linen, coverlet, flannel, wool, rag carpet, hearth rug, knit stockings, wool mittens, cotton hose, stocking yarn, jeans, barred flannel)

Class 26 Fancy needle work (ottoman cover, table cover, stand cover, silk embroidery, worsted work, lamp mat, crochet collars, imitation coral and shell work, muff, beaded bag, leather work, silk bonnet, counterpane; quilt)

Class 27 Bread, flour, preserves (flour; corn meal; yeast 
bread; salt rising bread; fruit, jelly and sponge cakes; grape, apple and currant jellies; plum, apple, quince, pear, watermelon and peach preserves; apple, peach and plum butters; tomato figs; tomato and plum catsups; cabbage, cucumber, plum, peach, onion and tomato pickles; homemade soap)

Class 28 Field crops (com, fall wheat, oats, Irish potatoes)

Class 29 Fruits (variety; fall eating, fall cooking, winter eating, cooking apples; pears and peaches; grapes; watermelon)

Class 30 Painting and flowers (pen drawing; monochromatic and oil painting; water color; collection and bouquet of flowers; house plants)

Class 31 Hams

Class 32 Miscellaneous

Premiums in the miscellaneous category went for an improved shingle machine, an improved bee hive, an improved loom imperial, tomato wine, continuous gum for setting artificial teeth, lightning rods, a shuck mattrass [sic], a moleskin hat, a self-soldering can and Sharp's American Breech Loading Rifle. Equestrian matches were held on the last day (Oct. 12) and prizes were awarded, although no class was specified in the premium list.

\section{Muscatine (1856-57)}

Muscatine hosted the third and fourth annual fairs in 1856 and 1857. All did not run smoothly. J. H. Wallace, secretary of the state society during both years, records, "No Society has ever held a Fair at which every person was pleased." It appears that fair-goers were unhappy with Muscatine hotelkeepers who "did extort by charging a dollar a bed." Private homeowners had agreed to take in lodgers during the fair, but the plan did not function well; Wallace surmises that either guests were unwilling to stay in private homes or the "Committee to Direct Strangers to Lodgings" did not perform its task-probably both.

The ticket-taking system presented problems too. Wallace estimates that in 1856 the society lost nearly $\$ 2,000$ revenue 
through ticket abuses. (A single adult admission was 25 cents.) As one example he cites:

The keeper of an applestand outside furnished many of his customers with a ticket to go in. This single [vendor's] ticket, which cost a dollar, was used in this way till it was literally worn out, and the boast was made by those who used it, that it had taken in a hundred men.

Lady equestrianism came under sharp attack in the 1856 report. Wallace notes that in a newspaper article covering the fair the space allotted to the various activities was divided in the following proportions: "THREE columns to the horses, cattle, crops and machinery of the State, and SIX to the sweet faces and beautiful riding-caps of some dozen ladies!" Later Wallace offers the opinion that the sport has a tendency "to draw woman away from that retiring delicacy of character, and gentleness of demeanor, which are her chiefest charms in every relation of life."

The society was criticized in 1856 for the "undue proportion of attention and time that is given to trotting horses." Wallace admits that although a man "may be examining a specimen of his favorite short-homs with almost infinite delight, the moment he is informed 'the horses are trotting,' he drops his short-horns, and rushes for the ring." Wallace defends the society's decision to include this category in the premium lists by arguing that (1) farmers are interested in improving the horse, (2) more money is invested in the horse than in any other class of animal and (3) the only way a horse can be judged is by seeing him in motion. To illustrate this last point Wallace relates the following example:

. . . many will remember a pair of three-year-old filleys that trotted together at the last State fair, in 3:20, owned and driven by Mr. [Joseph A.] Green of Muscatine. It will also be remembered that they were about as homely a pair of animals as were on the ground, 'barrel-headed,' 'mule-eared,' ugly-looking things, as you would see in a day's travel; but notwithstanding their homely appearance ... they took the first and second premiums in their class; then went to St. Louis, and did the same thing, where they had some four or five States to contend with. Why did they take those premiums? It was 
on account of their superior movement alone.

Lady equestrianism and horse trotting, both crowd pleasers, were ruled out in 1857. This same year, however, saw the beginning of better legislative support for the state society and its annual exhibitions. "An Act for the Encouragement of Agriculture" was approved by Gov. James W. Grimes on Jan. 28. The new act superseded the 1855 offer of patronage and pledged $\$ 2,000$ annual support for the society.

\section{Oskaloosa (1858-59)}

The fair was moved to Oskaloosa in 1858 where the camping system was tried for the first time on a large scale. Wallace, still holding office as secretary, reports:

A considerable number of the very best ladies in the State, were there with their husbands and families, and were not inside of a house from the time they left home till they returned after the close of the Fair. Parties having ladies in company will be permitted to camp inside the enclosure, costing them nothing but a small fee, sufficient to keep a good police force in and around the camp day and night. Many little conveniences will be provided for the encampment . . .

The camping system was retained in 1859 , which found the fair again at Oskaloosa. In this year an attempt was made to establish the distinction between throughbred and fullblooded animals for the purpose of classification and premium awarding. According to the Rules, "A thorough-bred animal must trace back in both the Paternal and Maternal lines as far as record, and even tradition goes without any admixture of other blood than that of the original race ... An animal ... is said to be 'full-blood' when it can trace six generations without any admixture."

A comparison of the 1859 premium list with that of 1855 gives some idea of how the fair had grown in just a few years. A new system of classification was established; it was composed of the following divisions and classes:

Division A (Cattle)

No. 1-Shorthorns; No. 2-Devons; No. 3-Herefords; No. 4-Alderneys; No. 5-Shorthorns, full blooded; No. 6-Grades and natives; No. 7-Milch cows; 
No. 8-Herd premiums; No. 9-Oxen, steers and fat cattle; No. 10-Sweepstakes

Division B (Horses)

No. 11-Roadsters; No. 12-Thoroughbreds;

No. 13-Farm horses; No. 14-Geldings and mares, paired and single, in heavy harness; No. 15-Matched and single horses or mares, in light harness;

No. 16-Jacks and jennets; No. 17-Mules

Division C (Sheep and Hogs)

No. 18-Fine wooled sheep, without regard to breed; No. 19-Long wooled sheep; No. 20-Hogs, all breeds; No. 21-Poultry, all kinds

Division D (Plows and plowing match)

No. 22-Plows; No. 23-Plowing match

Division E (Agricultural Implements)

No. 24-Cultivators, harrows, rollers and corn-planters; No. 25-Farmers' tools; No. 26-Farm implements; No. 27-Farm machinery

Division F (Mechanical Department)

No. 28-Vehicles; No. 29-Cabinet work;

No. 30-Farmers', coopers' and basket-makers' work;

No. 31-Wrought iron work, locks, etc.;

No. 32-Castings of iron and other metal; No. 33-Fine worked metals, plate, cutlery, plated, gilt and galvanized ware, clocks, watches and jewelry (American manufacture); No. 34-Philosophical, chemical, surgical, dental, drawing, painting, surveying and leveling instruments and apparatus, etc. of fine workmanship, exhibited by maker (American manufacture);

No. 35-Engines, machinery, etc. No. 36-Fabrics of leather, etc.; No. 37-Bookbinders', papermakers' and upholsters' work; No. 38-Printers' premium

Division G (Farm, Orchard, Garden and Household Products )

No. 39-Grain and seeds; No. 40-Vegetables; No. 41-Fruits, professional list; No. 42-Fruits, general list; No. 43-Grapes and their products;

No. 44-Flowers, plants, etc.; No. 45-Staple goods, 
household manufacture; No. 46-Fancy Goods;

No. 47-Pantry stores, No. 1; No. 48-Pantry stores No. 2

\section{Division $\mathrm{H}$ (Miscellaneous)}

No. 49-Musical instruments; No. 50-Sculpture, paintings, drawings, etc.; No. 51-Designs and models; No. 52-Natural history, geology, botany, etc.

Division I (Premiums to be Awarded in January)

No. 53-Reports of the fair; No. 54-Chinese cane and its products; No. 55-Essays; No. 56-Manny Prize; No. 57-Field crops.

The Manny Prize, a special premium, was offered to the farmer who had raised the best five acres of spring wheat. A combined reaping and mowing machine named for the inventor John H. Manny, it was presented to the Iowa State Agricultural Society by its manufacturers, Tallcott, Emerson \& Co. of Rockford, Ill.

During the state fair's first six years it had three different locations. For the next 20 years it continued to move from town to town: Iowa City, 1860, 1861; Dubuque, 1862, 1863; Burlington, 1864, 1865, 1866; Clinton, 1867, 1868; Keokuk, 1869, 1870, 1874, 1875; Cedar Rapids, 1871, 1873, $1876,1877,1878$. In 1879 the fair moved, for the last time, to Des Moines where it has continued to grow and to fulfill its original purposes.

\section{Sources}

Fairfield Ledger. Fairfield, Iowa: Nov. 2, 1854.

Gue, Benjamin F., History of Iowa, Vol. IV. N.Y.: The Century History Co., 1903.

Iowa Official Register (1967-1968), ed. Betty L. Lamberto. Des Moines: State of Iowa, 1969.

Regulations and List of Premiums of the Iowa State Agricultural Society (1857). Muscatine, Iowa: by the society, 1857.

Report and Proceedings of the Iowa State Agricultural Society (1885). Fairfield, Iowa: by the society, 1856.

Report of the Third Annual Exhibition of the lowa State Agricultural Society (1856). Muscatine, Iowa: by the society, 1857.

Rules, Regulations and Premium List of the lowa State Agricultural Society (1859). Dubuque, Iowa: by the society, 1859. 
Copyright of Annals of Iowa is the property of State of Iowa, by \& through the State Historical Society of Iowa and its content may not be copied or emailed to multiple sites or posted to a listserv without the copyright holder's express written permission. However, users may print, download, or email articles for individual use. 